\title{
Dialogue in community: conditions and enablers for teacher professional development in Catholic schools
}

\author{
Rina Madden ${ }^{1}$ (D) \\ Published online: 4 July 2020 \\ (c) Australian Catholic University 2020
}

\begin{abstract}
This article explores conditions and enablers for teacher professional learning in religious education in Catholic schools. It examines the impact on religion of the pluralising and secularising influences in Australia today and identifies what this asks of religious education and religious educators in response. New pedagogical approaches which emphasise identity formation as critical to religious education, make teacher identity formation and ongoing learning vital for Catholic schools to undertake. The article proposes that teacher professional learning in Catholic schools focus on developing the following three dispositions and skills: self-awareness and reflexivity; openness to faith perspectives; and courageous communication skills. The article investigates teacher professional learning theory and research to make recommendations for teacher development in religious education. It raises two concepts as integral to professional learning in a Catholic context: Dialogue and Community. These concepts are highlighted as theologically and strategically important for Catholic school communities to attend to and explore.
\end{abstract}

Keywords Teacher professional learning $\cdot$ Dialogue $\cdot$ Community $\cdot$ Religious education . Pedagogy

\section{Introduction}

Teaching is a moral endeavour motivated by supporting the full flourishing of students: physically, socially, spiritually and cognitively; which in turn impacts the society in which they live and grow for the common good. Teaching is also a complex task requiring decisions to be made in response to nuanced relational information and ongoing evaluative judgments. The teacher holds in tension the mandated aims of an outcomes based curriculum and the development and identity growth of the student, balancing demands from a variety of pressures extending from the local school culture to broader government policy directions and cultural expectations. Teachers' tacitly held beliefs influence the pedagogical choices they make in the classroom every day: beliefs about who they are as teachers and members of a Catholic

Rina Madden

rina.madden@ctc.edu.au

1 Pastoral Theology Dept., Catholic Theological College, Melbourne, VIC, Australia 
school community, who their students are and can be; as well as beliefs about the relevance and importance of the curriculum they are teaching. It is vital for classroom practitioners to engage in ongoing professional learning that explores the complexity of learning and teaching in context and gives teachers an opportunity to bring to light beliefs and assumptions that influence their pedagogical choices.

For religious educators there is additional complexity in bringing to light tacit beliefs and attending to professional development needs compounded by the contested nature of religious education and differing opinions regarding the pedagogical approaches needed to respond to a changing religious landscape. For Catholic schools the current religious landscape is influenced by Vatican II theology expressed in The Pastoral Constitution on the Church in the Modern World, Gaudiem et Spes (1965a) and The Dogmatic Constitution on Divine Revelation, Dei Verbum (1965b). These documents present a watershed for Catholic selfunderstanding which embraces engagement with the world and other faith perspectives and proclaims a dialogical God who "speaks to men as friends" (DV, 2). The theological language reflects a focus on interiority and an understanding of the tradition as one which is open to change and growth through a three way dialogue of faith that engages: the spiritual realities experienced by all; the fruits of contemplation and study of the tradition; and the preaching of the Bishops. Understanding the Catholic tradition as dynamic and responsive calls for new ways of teaching and learning about the tradition which empowers learners to interpret the tradition for their time and context, involving them in ongoing recontextualisation of the tradition (Boeve 2003). A new Catholic self-understanding asks religious educators to engage new approaches to religious education in Catholic schools such as a hermeneutical communicative pedagogy (Pollefeyt 2008). This approach seeks to open dialogue with students about faith perspectives in making meaning of the big questions of life and current issues. However, new learning and teaching approaches raise the question of how to support teachers in understanding their role in this changing religious landscape.

This article explores conditions and enablers for teacher professional learning in religious education in Catholic schools. It examines the impact on religion of the pluralising and secularising influences in Australia today and identifies what this asks of religious education and religious educators in response. New pedagogical approaches which emphasise identity formation as critical to religious education make teacher identity formation and ongoing learning vital for Catholic schools to undertake. The article proposes that teacher professional learning in Catholic schools focuses on developing the following three dispositions and skills: self-awareness and ongoing identity formation; openness to faith perspectives; and courageous communication skills as critical to empowering and skilling learners to interpret the Christian tradition in seeking truth for living today. The article investigates teacher professional learning theory and research to make recommendations for teacher development in religious education. It raises two concepts as integral to professional learning in a Catholic context: Dialogue and Community. These concepts are highlighted as theologically and strategically important for Catholic school communities to attend to and explore in pursuing teacher development in religious education.

\section{Australian religious context}

Western European society reflects a post-Christian context (Houtman and Aupers 2007) where de-traditionalising, individualising and pluralising influences (Boeve 2003) reduce the possibility of religion as having an influential public voice. These influences are also 
reflected within Christian communities, revealing increasingly diverse interpretations and fragmenting religious identities as internal factions struggle to make sense of the changing religious and global context. The Australian scene provides a subtle distinction in this struggle. Australia has been coming to terms with itself as a 'multi-cultural society' since 1973 when the phrase was introduced in a paper by the Minister for Immigration Al Grassby to the then Whitlam Government. Religious diversity is acknowledged as one aspect of cultural diversity and freedom of religion is enshrined in inclusive public policy in Australia. However, historically religion has been relegated to the private sphere with distinct separation between religion and state and no common public rhetoric that mentions God. It is unusual for Australians to overtly display any religiosity and there are no common cultural expressions relating to religion (Christmas and Easter having been largely secularised and commodified). While the majority of Australians remain nominally Christian, the Australian Bureau of Statistics data (2016) indicate that the 'no religion' category has increased by almost 50 percent in the years 2011 to 2016, with the median age of 44 for those nominating as Christian. Particularly for today's younger people then, a secular worldview is one they are comfortable with socially and politically with public theological or religious language receiving little critical or robust attention on the few occasions it occurs in the media. This raises a concern for teachers whose focus is to bring into dialogue the issues of the day with religious perspectives of Catholic and other religious traditions. Teachers in Catholic schools are not immune to the cultural reticence around religious language, compounding the difficulty of bringing to speech ideas about God and faith in a classroom of young learners and highlighting the importance of professional development in this area.

Since the Corona Virus pandemic swooped into Australia in January 2020, the cultural picture has altered significantly giving urgency to making meaning of an unprecedented global upheaval which is interrupting all aspects of reality as we know it. It has brought into sharp relief a need to find new ways to honour the social and ethical responsibilities embedded in our human vulnerability. Religious education is in this context a vital domain of learning with young people, one that can embrace a turn to the existential questions of life as students grapple with radically altered circumstances and re-think how they can be and act in this world. At this time, a recontextualising religious language that eschews literalism and apocalyptic language is needed in the public domain to fight nihilism and dogmatic tendencies; speaking out for solidarity and compassion for our neighbour, humility in the face of the unknown beyond our control, and respectful relationship with the earth.

In this new context there is a new urgency for religious educators to come to grips with a religious language and method which embraces existential questions and seeks hope in supporting students to make meaning of their lives in dialogue with the Catholic faith tradition and in awareness of other faith perspectives. A religious educator today requires

- self-awareness and ongoing identity formation

- openness to faith perspectives

- courageous communication skills

Self-awareness enables the teacher to examine their own beliefs and perspectives in context and be comfortable with the uncertainty of a changing and growing identitytheir own and that of their students. As reflexive practitioners, they attend to and respond to their students' concerns with a focus on improving their approach. Openness to faith perspectives entails grappling with a perspective on life that acknowledges the invisible 
Transcendent at work as unknown and unknowable. Openness to faith makes it possible for the teacher to witness to encounter and interruption (Boeve 2003) as that which reveals something of the Transcendent and the eternal issues inherent in life. Openness to faith perspectives is particularly important in engaging students in reimagining and awakening to a hidden Transcendent. Courageous communication skills enable the teacher to articulate clearly and in attractive ways what may often be counter-cultural understandings; honestly inquiring into the big questions and eternal issues inherent in students' lives and seeking a hopeful orientation. In today's climate, this may mean embracing technology in ways that prioritise what is valued in a relational and dialogical pedagogy such as the hermeneutic communicative approach.

Self-awareness, openness to faith, and courageous communication skills are indispensable teacher attributes that are critically important if Catholic schools are to continue to be places of flourishing and learning in the Catholic tradition. These dispositions and skills are able to be developed through ongoing professional dialogue and learning in community. It is vital that teachers engage in quality professional development in religious education, confronting their tacit beliefs and becoming more critically aware of who they are as religious educators. This article will examine the teacher professional learning theories of Brookfield, Timperley, Cameron, Pollefeyt, Haers and others to identify ways they support the above-mentioned three areas of development critical to religious educators today.

\subsection{Teacher self-awareness and ongoing identity formation}

The "end of the master narratives" is a phrase introduced by Jean Francois Lyotard (1979) as a way of describing the so-called post-modern era. Lyotard's description of the end of the modern era refers to the end of a common worldview being used to explain how things work and why they are so. The post-modern era saw a turn to the subjective in many fields of human endeavour, reflected in an enchantment with the personal, the particular and the local, resulting in increased plurality and complexity (Pollefeyt 2009; Tacey 2000; Tracy 1979). Research in the field of education has not escaped this trend with a focus on identity formation both for students and teachers. Religious education too has turned from a focus on imparting the 'treasures of the tradition' to engaging students in constructing their identity in light of Catholic worldviews (Pollefeyt 2009). Investigating teacher education trends, Rodgers and Scott (2008) note over the past decade research has revealed the complexity of the role of the teacher and the importance of understanding teacher identity formation; of taking into account their beliefs, personal narratives and unspoken attitudes and worldviews. They identify a shift in the focus of research from what teachers need to know to how they learn to teach. Rodgers and Scott trace the rise of teacher education programs that promote teacher self-awareness. These programs had in common that they "... valued close observation of and inquiry into children's learning as well as the world around them and recognised the role that the teacher's perceptions and preconceptions played in learning to see children and their learning." (Rodgers and Scott 2008, p. 744) Reviewing the literature (Hargreaves 2001; Zembylas 2003; Smagorinsky et al. 2004) it can be noted that personal and social orientations, colour what teachers pay attention to in the classroom and in their practice, as well as influencing their ability to critically reflect on their learning needs and the needs of their students. Identity formation is at the heart of both student and teacher learning and Rogers and Scott have summed up four understandings that underpin current conceptions of identity: 
(1) that identity is dependent upon and formed within multiple contexts which bring social, cultural, political, and historical forces to bear upon that formation; (2) that identity is formed in relationship with others and involves emotions; (3) that identity is shifting, unstable, and multiple; and, (4) that identity involves the construction and reconstruction of meaning through stories over time. (2008 p. 2)

Teachers may shift in how they understand themselves and their role through addressing the four understandings - reflecting on the contexts, relationships, emotions and stories that shape them. Rodgers and Scott identify that while context and relationships form external aspects of identity formation, these must be held in tension with the internal aspects of stories and emotions. In this sometimes uneasy encounter between internal and external forces, the teacher makes meaning, surfaces tacit beliefs and is challenged to new awareness of her identity. In exploring research into teacher beliefs, Skott (2015) has unpacked the methodological problems of linking beliefs to practice and notes the difficulty researchers have in differentiating beliefs from attitudes and other affective attributes. Despite noting this confusion of terms, his conclusions concur with Rodgers and Scott that research into teacher beliefs is opening up new understandings of the teacher's role and insights into ways teachers make pedagogical choices. Hattie and Yates (2013) and Helen Timperley (2007) have each presented persuasive research which link teachers' beliefs and expectations of their students to student outcomes. Their research grows out of the work of Jerome Bruner (1996) who maintains that teacher language and methodology in the classroom is "a direct reflection of the beliefs and assumptions the teacher holds about the learner." Despite teacher expertise, or content knowledge, the beliefs and assumptions held by a teacher about their students is often perceived by the student and impacts self-efficacy and outcomes. In order for teachers to develop their expertise, underlying beliefs must be addressed. Timperley's research has synthesised evidence from hundreds of research projects focusing on teacher development in New Zealand, Australia, Britain and America to make recommendations around best practice in teacher development. She identifies the importance of reflecting on tacit beliefs if teachers are to understand their own motivation and build awareness of their practice and its impact:

Tacit knowledge is built up over time and embedded in personal experience. It is accepted because it is known to work, but it can be a deterrent to creating change because it is often unexamined and unquestioned. Because an individual's educational values and beliefs are nested in a complex web of social and cultural history, challenge inevitably creates issues of identity, personal dissonance, and motivation. (2007, p. 13)

To overcome deterrents to changing and improving practice, Timperley identifies three processes that were found to help teachers examine and question their beliefs and values: cuing prior knowledge, developing awareness of new information and creating dissonance. These processes are embedded in the Action Research Cycle (2007) for teacher professional learning developed by Helen Timperley as a result of her research. This cycle involves four progressive movements: (a) reflection on practice, informed by theory, research and student feedback (which often creates dissonance); (b) identifying both student and teacher learning needs based on the reflections; (c) designing targeted tasks and learning experiences; (d) teaching actions; (e) reflecting on student evidence to identify the impact of actions. These movements are used over successive cycles to heighten teacher self-awareness and reflection on practice. Often the dissonance that 
helps teachers question their beliefs and assumptions is created in the cycle through the reflection on student feedback or student evidence of learning, which can at times be confronting.

Creating dissonance as a condition for self- reflection is also identified by John Loughran as an important element of teacher learning in What Expert Teachers Do (2010). He highlights the importance of teachers to be learners of their profession through exploration and experimentation which involves challenge and uncertainty. He states: "Learning to be comfortable with uncertainty is then part of what it means to become a learner of teaching and is at the heart of that which supports the development of pedagogical expertise." (2010, p. 39)

Being drawn into uncertainty through the creation of dissonance necessarily shakes teachers' beliefs about how to teach and what a teacher is called to be; it begins to bring into question what the goals of learning are. From uncertainty new questions arise leading to the possibility of growth. Due to government responses to the Corona virus pandemic, uncertainty is currently the 'wallpaper' of the educational community as teachers grapple to translate pedagogical approaches in teaching and learning from what is essentially a relational activity to one that can be performed in isolation. For religious educators this context colours self-reflection and raises questions around how faith understandings and experiences can be communicated through processes online.

Teacher development processes that increase self-reflection and support identity construction emphasise collegiality, reflection on practice and professional dialogue that is student focussed and research informed have been advocated by authors Brookfield (2017) and Fisher (2009). Brookfield in his research into effective adult education methods identifies professional dialogue as one of the most important factors in becoming a critically reflective teacher. He describes four complementary lenses through which adult learners can view their practice and identity: the adult learner's autobiography or their voice, colleague's perceptions, engagement with theory, and feedback on practice through students' eyes. The voices of the self, colleagues and students are all able to be physically or virtually present, while the voice of the 'other', which may provide an external lens, is brought to the dialogue through research or theory readings, heuristics, or an external expert can be invited to moderate or contribute to the dialogue. Each of the four voices carries equal weight in the professional dialogue, providing a variety of worldviews and experiences to contribute to self-reflection and reflection on practice.

This model, like that of Timperley is grounded in extended opportunities for dialogue to bring to speech tacit beliefs that may hinder change and growth. Fisher (2009) too proposes dialogue as a powerful model for learning as it promotes inquiry and curiosity through the surfacing of problems and the use of open ended questions. He notes that dialogue "builds intelligence, expands consciousness and provides a model for productive human relationships." (p. 200) Fisher advocates a community approach to reflective practice which includes teachers, students and parents in dialogue.

While many Catholic primary schools have created Professional Learning Teams (PLTs) which meet regularly to reflect on student evidence or plan collegially, these opportunities for collegial dialogue are not always aimed at teacher identity formation. In a secondary school context complex timetables allocate teachers and students to short periods of learning interactions (lessons), however, the timetable rarely includes teacher to teacher learning interactions. This indicates that a collegial approach to reflecting on teaching and learning and teacher identity formation have not been given due consideration. In the current upheaval to the ways of working, this might be an opportune moment to place greater emphasis on teachers as self-reflective practitioners and create space within school 
structures to bring to light teachers' tacit beliefs and assumptions through the enablers of dissonance, dialogue and collegial inquiry, strengthening teacher identity formation and self-awareness.

\section{Openness to faith}

In a Catholic context, dialogue is a process that holds a theological dimension, acknowledging the infinite Other as revealed in discourse (Levinas 2013, p.76). To enter into dialogue as a teacher in a Catholic school is to grapple with a Christian anthropology that understands the human person as made in the image of God (Anderson 1991), inviting each person to acknowledge infinite possibility found in the other. It is important for Catholic schools to notice and name the theological grounds for establishing dialogue processes and routines of dialogue structures which affirm and invite respectful interactions and intentionally build trust, building a culture of dialogue. These are conversations which explore religious perspectives and big questions that lie at the heart of identity and faith, giving expression to a variety of ways of noticing and naming the sacred. To be part of such conversations with their peers is a vital experience for teachers if they are to engage students in dialogue as part of a rich and relevant religious education (Madden 2017).

There are challenges to setting up a culture of dialogue which invites teachers to be open to faith perspectives. This invitation can only be realistically extended if two conditions are also in place: the intentional use of protocols and processes that build relationships of trust and ensure confidentiality; substantive time prioritised for reflection and exploration in dialogue with colleagues. As discussed above, public debates or even social conversations about religious or spiritual perspectives on current issues are rare. Culturally relegated to the private sphere, religion is also a difficult topic to initiate in a professional learning conversation. There are three enablers to support teachers opening themselves to a faith or spiritual perspective in a school professional learning context:

- Engaging with an alternative paradigm of education

- Creating space for transformative dialogue using processes and heuristics

- Grappling with religious worldviews as positive and relevant

\subsection{Engaging with an alternative paradigm of education}

Teachers are immersed in the prevailing model of education which has become tied to a productivity and market orientation dictated by a culture that is more comfortable applying the language of economics to education than the language of philosophy or spirituality. This is identified by Roz Sunley (2009) who claims that spirituality is rarely at the centre of conversations in education:

It (spirituality) is contentious in its definition, obscure in its language and lacks confidence in its operation. It is not easily measurable and it provides little impact to those who see education in more prosaic terms. In a world of economism, it appears to add little of economic benefit. In short, it requires people of conviction and of passion to insist on its place in education. In a society that is increasingly 'risk averse' the idea of promoting a domain of human development that cannot readily be identified or measured requires true conviction. (p. 797) 
Sunley names true conviction as the key element to grappling with the spiritual dimension in education. While this element may not be uniformly found across all staff at Catholic schools, it needs a core group, specifically system leaders, to be so convinced that they confidently keep spirituality and faith on the teacher learning agenda and promote it as offering an alternative paradigm for education.

Catholic Education Melbourne has put forward such an alternative paradigm in their system learning and teaching framework Horizons of Hope (2018). In dynamic and visionary language the framework urges all Catholic schools in the Melbourne Archdiocese to support students to grapple with a Catholic word view that believes the world and each person in it is created by a loving God and is therefore inherently good and full of hope and open to new possibilities. It is a vision that puts spirituality at the heart of education. The framework urges this engagement with a Catholic worldview across all curriculum areas, not just through the subject area of religion. Through dialogue with the Catholic tradition students are actively called into processes of discernment relating to their identity and to respond to a felt call to act for justice and with integrity. The framework uses the Post Conciliar statements on the Catholic school (The Catholic School on the Threshold of the Third Millenium, 1977 and The Religious Dimension of Education in a Catholic School 1988) which describe the distinctive nature of the Catholic school and its pedagogical approaches. Horizons of Hope proposes a goal that students in Catholic schools may be able to "experience success and be supported to see their lives as being shaped by the God who is at work in all creation." (Vision and Context, p. 6) This learning and teaching framework describes a pedagogy that "empowers learners to seek truth, and to question and critique the prevailing cultural and philosophical ideas within the world around them." (Pedagogy in a Catholic School p. 3)

The powerful vision for a Catholic pedagogy across the curriculum in Horizons of Hope is an opportunity to engage with and challenge the prevailing utilitarian model of education (at time of writing this model is being highlighted in newly announced Australian Government funding policies for Universities which aim to make humanities subjects significantly more expensive, attempting to manipulate students to choosing science and engineering as preferred 'employment ready' options). Professional dialogue in light of the framework as a theoretical voice in the teacher learning dialogue can raise issues around the broader goals of society and how these goals impact student learning in their school context. Engaging with a Catholic vision for learning such as Horizons of Hope or the Vatican document Educating Today and Tomorrow (Congregation for Catholic Education 2014) may present new possibilities for learning design for students and uncover assumptions teachers may have about what a successful Catholic education can and should achieve for students and for the wider community. It focuses the conversation on broader understandings of faith perspectives, unpacking what a faith perspective can bring to students' learning and offering a way to open faith conversations with teachers through conversation starters and discussion questions aimed at promoting dialogue in staff meetings and learning team meetings.

\subsection{Creating space for transformative dialogue using processes and heuristics}

An enabler for opening teachers to faith perspectives is when space is created for transformative dialogue. Prioritising time for professional dialogue is the first and foremost challenge in creating space for dialogue. In Catholic schools the opportunity for reflection and dialogue once identified as a priority may present difficulties in its application. How to 
talk about God with peers and with students may be a daunting task when it has not been attempted before. Engaging teachers with multiple faith perspectives and a theological dimension in teacher professional dialogue takes some skill and requires modelling. One approach is described in the research by Helen Cameron et al. (2010). In their work, they advocate a Theological Action Research approach (TAR). Similarities can be drawn between the Timperley action research cycle (2007) and TAR, which uses the movements of Learning, Action, Experience and Reflection. The difference Cameron stresses is that theology is an integral part of each of these movements. She understands that the group involved in this research approach is a faith-led Christian community who gather "as persons seeking together."(p. 57) As with Timperley's action research cycle, TAR is also committed to open dialogue where inviting and valuing a diversity of views and voices is seen as a strength. One of the characteristic features of TAR is an understanding of theology as expressed in four interrelated voices, offering insight into the complexity and dynamics of theological reflection processes. These four voices: Normative, Espoused, Formal and Operant theology, (p. 54) have a distinct role in dialogue. The Espoused and Operant theologies of practitioners have their own authority and have a role in challenging, forming and informing the Normative and Formal theologies of the 'professional' theologians and vice versa. It is a useful tool to analyse the theologies brought into conversation and helps to challenge tacit beliefs and to bring to speech unarticulated theologies.

The notion of community is critical to creating space for transformative dialogue and theological reflection in the TAR approach. Focused on the transformation of the participants, the community is seen by Cameron as already a community of faith in action with both implicit and explicit theologies operating. The community is transformed in part "through the empowerment of discovering and forming a language for the often hidden depths of what we do."(p. 58) As working within a Catholic faith community, teachers are invited to open themselves to the various faith perspectives found in that community and to contribute actively to forming the language and flavour of the faith as lived in that community. A community orientation to opening oneself to faith perspectives is consistent with the Congregation for Catholic Education's document Educating Today and Tomorrow (2014). This document shifted the emphasis on the identity of the Catholic school from being an institution delivering education to being an educational community. With this change comes a challenge to focus on relationships and community building processes that build a culture of learning open to faith.

As a way of enabling teachers to open themselves in discussions around faith perspectives it is useful to employ a heuristic. Heuristics are exploratory and investigative frameworks that employ experiential or empirical data to help make concrete what may otherwise be abstract. Two heuristics that explore faith perspectives and support teachers to open themselves in dialogue around faith are the Enhancing Catholic School Identity Project (ECSIP) survey instruments (Pollefeyt and Bouwens 2014) and a Framework of Christian Spirituality for teachers and students developed in $\mathrm{PhD}$ research by this author (unpublished 2019).

ECSIP is a project initiated by the Catholic Education Commission of Victoria in partnership with Katolieke Universiteit Leuven in 2006 to develop and refine empirical survey instruments that analysed, described and suggested ways for enhancing Catholic schools' identity (Pollefeyt and Bouwens 2014). ECSIP is now a methodology applied extensively in Catholic schools in Australia and Flanders as well as being trialled in many other parts of the world. It is having a profound effect on the language used to describe Catholic identity and religious education in Catholic schools. The data from the Post-Critical Belief (PCB) Scale, one of the three scales used in ECSIP, reveals 
information about ways people deal with belief content, or religious concepts such as a Transcendent being. Based on a concept by David Wulff, the scale describes four ways: Literal belief, Post-critical belief, Relativism and External Critique. The first two indicate belief, while the latter two reject belief (External Critique), or hesitate to commit to a particular belief (Relativism). The whole school community including teachers, leaders, parents and students participate in online surveys that place them in one or all of the four styles. In unpacking the survey data and discussing what this means for their school and their pedagogical approaches, teachers are opening up deep issues of faith and belief, discussing questions which arise such as: What might it indicate about our teaching approach if students are reflecting literal belief, yet the teachers indicate strong support for a post-critical believing style? What might it mean for our future as Church if older students favour relativism? The Melbourne Scale generates discussion around how religion is presented in the school environment, while the Victoria scale focuses attention on pedagogical approaches. Each of the scales intersect to create a picture of the complex and diverse ways of being Catholic present in the school. By focusing on unpacking whole school data, the descriptions and language used in the heuristics support teachers to grapple with their own perspectives on faith and how that impacts their pedagogical decision-making in the classroom.

To engage teachers in dialogue that touches on more personal faith understandings and using existential language, a heuristic was developed through this author's $\mathrm{PhD}$ research (2019). In this research empirical data around teachers' understandings and beliefs about their spirituality and that of their students informed the construction of a framework of Christian spirituality. The framework described four paradigms of human spiritual experiencing in relatable language that reflected Apophatic and Kataphatic theological orientations: Commitment and Fulfilment (Kataphatic) and Vulnerability and Responsibility (Apophatic). In using the framework to explore pedagogic practice, teachers noticed that their curriculum foci largely neglected the spiritual paradigms of Vulnerability and Responsibility, preferencing the positive or Kataphatic theology of the paradigms of Commitment and Fulfilment. Using the framework, teachers were enabled to explore questions around the types of images of God and the kinds of spiritual experiences that were being highlighted or neglected with students in religious education classes. Using the heuristic also supported teachers to critique a Christian Values Education approach in religious education that is common in Catholic schools (Pollefeyt and Bouwens 2014). They engaged in rich theological discussion that gave them new insights into their own spirituality. The Kataphatic and Apophatic traditions which are held in tension in the framework set up a dialogue about ways of speaking about God through human experience and relationship, balanced with understanding God as hidden and Other, all of which are reflections of revelation found in the human experiences of Vulnerability, Responsibility, Commitment and Fulfilment. Through engaging with a heuristic which explores the Christian spiritual tradition in its fullness teachers are enabled to rediscover faith not only as a deposit of treasured and time honoured tradition, but as a process of dialogue which walks alongside doubt and is strengthened by questioning.

Using intentional processes and structures such as TAR or adapting other dialogue protocols and heuristics such as the ECSIP survey instruments or the Framework of Spirituality will scaffold teacher professional dialogue and promote openness to faith perspectives. 


\subsection{Grappling with religious worldviews as positive and relevant}

In supporting teachers to be open to faith perspectives the third important enabler is to promote religious worldviews as positive contributors to deep learning. It is incumbent upon teachers to bring into dialogue diverse worldviews to critique and illuminate each other. Balancing a turn to the spiritual with a movement away from organised religions, reflecting on the voice of conscience when responding to the call from the other, creating a space for stillness and prayer while grappling with pressures of social change and a perceived absence of God, are all part of the tensions which form the very fabric of dialogue with students and with colleagues in religious education. How these tensions are handled and in what light a religious perspective is presented in the religious education classroom are influenced by the teachers' own religious profile and attitude to religion as a plausible option. It is therefore important that competing worldviews be intentionally raised in the professional learning agenda for religious educators. In professional learning, teachers can deepen understanding around the issues of the day through positing the questions religious perspectives can bring, which challenges the content of any subject area to broaden their perspectives to include a Transcendent dimension the eternal issues inherent in life and the transformative possibilities of learning.

When religious worldviews are viewed positively, they become an integral part of the dialogue alongside cultural and professional issues of the day. Not every teacher will contribute a specifically faith perspective, and not every faith perspective will reflect an orthodox viewpoint; however, in the transformative process of dialogue, each contribution can engender questions and perspectives that challenge, add to or deepen faith understandings. This form of multi-correlational dialogue entails substantive commitment by school and system leaders to insist on prioritising professional dialogue that invites a variety of viewpoints while at the same time presenting the Christian narrative as a preferred option. In the words of Catholic identity researchers Pollefeyt and Bouwens, "Being truly open and receptive towards 'otherness' is an integral part of what it means to be Catholic.'(2014, p. 3016) When schools establish respectful relationships of trust through a focus on dialogue which highlights its theological, relational and transformative dimensions, it creates a culture of dialogue that approaches religious worldviews positively and opens teachers and students to exploring faith.

Engaging with an alternative paradigm of education, intentionally creating conditions for transformative dialogue and grappling with religious worldviews as positive and relevant, are three processes or strategies that can be enacted in a school based professional learning program to support teachers to be open to faith perspectives and critically reflect on their own faith and beliefs.

\section{Courageous communication}

Teaching is defined by two interconnected skills; listening and speaking. Teachers must be able to listen deeply and with empathy to seek to understand the other, and at the same time they must be able to adapt their language to communicate according to the level of language skills and world experiences of the students. These communication skills reflect an understanding of the skills and processes of dialogue which is vital for the teaching profession. In the case of religious education, there is an added element of courage involved 
which empowers the teacher to be attuned to recontextualising the language of theology in partnership with students (Pollefeyt and Bouwens 2014). Recontextualising religious language is a creative task, one that is enacted in dialogue, requiring an appreciation and knowledge of the tradition in which the language and its concepts are grounded. Teachers' role in this communication task is couched in terms that demonstrate this task is communal, not individual as found in the words of the Vatican document Educating Today and Tomorrow:

The whole professional and educational community is called upon to present faith as an attractive option, with a humble and supportive attitude. The model is provided by Jesus Christ and his disciples in Emmaus: we must start from young people's life experience but also from that of co-workers, to provide an unconditional service. (Congregation for Catholic Education 2014)

Importantly this passage points to the communal nature of the model of communicating faith. It highlights the contextualised and interpretative nature of theology and its need to respond to the life experience of young people and colleagues. Indeed, while teacher professional learning is often taken as a personal development responsibility, it is in fact an integral part of the school learning culture. Teachers must be embraced as learners within the whole fabric of learning in the school for ongoing learning and teacher development to take place. Jacques Haers (2004) emphasises the importance of relationships and conversation or dialogue as the basis for the school as a "community of discernment." (p. 313) Such a community would support teachers who he sees as often vulnerable people who are grappling with their identity and challenges to their authority. He suggests that teachers are important building blocks for the creation of a learning community. While he does not attempt to establish a teacher development theory, he names a particular role for 'direction staff' or leadership. He highlights the importance of leaders consciously articulating their faith and inviting others to do so by initiating dialogue opportunities between parents, teachers and students in a variety of settings and groups. In this way leaders better discern what's at stake in the school community and actively promote the building of the community. He sees leadership as playing a vital role in setting the agenda for school community discussions about "what is important and worthwhile in human life and about how these important elements may be achieved."(p. 329) This is a spiritual agenda which, Haers maintains, creates a space for a religious education where each person is positioned as a learner and is actively encouraged to pursue learning and faith development. In pursuing this spiritual agenda, a community is formed which is comfortable with and confident in communicating religious concepts and ideas.

One example of a school leadership which has undertaken to ensure teachers can increase their communication skills and confidence in opening a spiritual agenda and recontextualising theological language is that of St Joseph's Catholic Primary School Hawthorn. This school structures teacher professional dialogue that intentionally addresses learning concepts in dialogue with Catholic and other religious traditions. (Madden 2017) These regular sessions are timetabled to ensure teachers from the same level of schooling are free to engage in robust discussion that allows for dissent, argument, rational deliberation and freedom to engage with multiple perspectives, which includes student voice in the form of the questions students bring. Through these sessions, teachers are enabled to develop the confidence and competence around a language of faith and religion that makes sense to them and makes connections with the learning concept they are planning to engage students in. This school believes the Christian tradition has something positive to offer teachers and students and acknowledges the importance of offering 
teachers a 'practice space' with an external voice such as that of a religious expert or a theologian to enhance and enrich their communication skills in religious education.

\section{Conclusion: Dialogue in Community}

Teachers are themselves aware of the importance of ongoing faith formation and development of practice in religious education as indicated in the following quote from a religious educator in a Melbourne Catholic primary school who participated in research for $\mathrm{PhD}$ thesis conducted by this author:

The teachers have to develop their spirituality, I suppose what I'm trying to say, before they can become good at imparting that or helping their students too - and just luckily for me I've been at the right schools where that has been of high importance to principals. And then finding the right consultants for us to work with because, unless ... I would have stuck myself in the seventies and eighties I suppose... and not gone any further, I'm guessing, unless I had had this chance to unpack my spirituality as an adult and as a teacher.

In the above quote, this teacher is acknowledging the importance of being positioned in the school as a learner as well as a teacher. In a Catholic school context, both dialogue and community are concepts that hold theological dimensions and are the two concepts that are key to ongoing teacher development. Community is a significant principle of Vatican II and in Lumen Gentium, the vision for the Church as the People of God elevates the importance of each member of the community, who are all called to holiness (LG 39). It also acknowledges the "wonderful diversity" in community (LG 32) which allows for no inequality between different members, regardless of age, race or standing. In being true to this principle of community, Catholic schools will seek to invite the voices of students, teachers, leaders and parents equally into dialogue and will be aware of the diverse perspectives these voices bring, providing opportunities to surface new understandings and language about God's self-communication. A religious educator today requires selfawareness and ongoing identity formation, openness to a faith perspective and courageous communication skills and to come to grips with a new religious language and method required in a pluralising, secularising and disrupted context. Through dialogue and learning in community, teachers are supported to develop all three.

In summary, this article has described the changing religious landscape influenced by the second Vatican Councils' new understanding of an outward facing, dialogical Church in relation to the world, with particular attention to Australia's multi-cultural and currently disrupted context. It highlighted the move to new teaching approaches in religious education that emphasise identity formation in response to this context and the need for intentional, ongoing, dialogical and school community led professional development that enhances teacher identity formation. It identified three important teacher attributes towards which teacher professional learning could be directed: self-awareness and identity growth; openness to faith perspectives; and courageous communication skills. The article explored teacher professional development theory and research to make recommendations around powerful strategies that enable teacher professional development in religious education. Creating dissonance in dialogue and inviting a variety of voices into dialogue including the voices of students, colleagues, their own narrative and the theoretical or theological enabled teachers to surface and challenge their tacit beliefs about themselves as teachers, 
how they understand teaching and learning and how they understand their learners. Engaging with an alternative paradigm of education, creating space for transformative dialogue using processes and heuristics and grappling with religious worldviews as positive and relevant enabled an environment of trust where teachers could be open to explore their own and other faith perspectives. Courageous communication skills were seen to be developed when leaders created a community of learners in dialogue with each other and intentionally set the dialogue agenda to inquire into the big questions of life and faith. The strategies identified in the professional learning theories discussed can be summed up as strategies which employ intentional processes to engage teachers in critical self-reflection and professional dialogue as a community of learners.

In conclusion, research into teacher professional learning theory from within a theological framework or outside it acknowledges that it is vital to knowledge and skill development that teachers are supported by leadership in schools who offer the opportunity to build ongoing professional relationships in a community of inquiry and give quality time for teachers to critically reflect on their beliefs and practice through dialogue. This critical reflection is informed by theory and brought to the surface by dissonance. Specifically in the Catholic context, the Catholic intellectual and spiritual traditions, as well as its lived practice in the school community are vital sources for a teacher reflection action cycle where theology is part of every phase.

\section{Author contributions None.}

Funding None.

Code availability None.

\section{Compliance with ethical standards}

Conflicts of interest The authors declare that they have no conflict of interest.

\section{References}

Anderson, R. (1991). On being human: Essays in theological anthropology. Pasadena California: Fuller Seminary Press.

Australian Bureau of Statistics. (2016). Census Data Media Release. Retrieved April 17, 2020, from https ://www.abs.gov.au/AUSSTATS/abs@.nsf/mediareleasesbyReleaseDate/8497F7A8E7DB5BEFCA25 821800203DA4?OpenDocument.

Boeve, L. (2003). Interrupting tradition: An essay on Christian faith in a postmodern context. Leuven: Peeters.

Brookfield, S. (2017). Becoming a critically reflective teacher (2nd ed.). San Francisco: Jossey-Bass.

Bruner, J. (1996). The culture of education. Cambridge, MA: Harvard University Press.

Cameron, H., Bhatti, D., Duce, C., Sweeney, J., \& Watkins, C. (2010). Talking about God in practice: Theological action research and practical theology. London: SCM Press.

Catholic Education Melbourne. (2018). Learning and Teaching Framework: Horizons of Hope. Retrieved March 11, 2020, from https://www.cem.edu.au/Our-Schools/Curriculum/Horizonsof-Hope.aspx.

Congregation for Catholic Education. (2014). Educating today and tomorrow: A Renewing passion. Retrieved April 21, 2020, from https://www.vatican.va/roman_curia/congregations/ccatheduc/docum ents/rc_con_ccatheduc_doc_20140407_educare-oggi-e-domani_en.html.

Congregation for Catholic Education. (1977). The Catholic school on the threshold of the third millenium. Retrieved June 21, 2020, from https://www.vatican.va/roman_curia/congregations/ccatheduc/docum ents/rc_con_ccatheduc_doc_27041998_school2000_en.html. 
Congregation for Catholic Education. (1988). The Religious Dimension of Education in a Catholic School. Retrieved June 21, 2020, from https://www.vatican.va/roman_curia/congregations/ccatheduc/docum ents/rc_con_ccatheduc_doc_19880407_catholic-school_en.html.

Fisher, R. (2009). Creative dialogue: Talkfor thinking in the classroom. London and New York: Routledge.

Haers, J. (2004). Religious education as conversation: Schools as communities of discernment. In H. Lombaerts \& D. Pollefeyt (Eds.), Hermeneutics and religious education (pp. 313-334). Leuven: Peeters.

Hargreaves, A. (2001). The emotional geographies of teaching. Teachers College Record, 6(103), 1056-1080.

Hattie, J., \& Yates, G. (2013). Visible learning and the science of how we learn. London: Taylor and Francis Ltd.

Houtman, D., \& Aupers, S. (2007). The spiritual turn and the decline of tradition: The spread of postChristian spirituality in 14 Western Countries, 1981-2000. Journal for the Scientific Study of Religion, $46,305-320$.

Levinas, E. (2013). Totality and infinity: An essay on exteriority. Trans. Lingis, A. 1969, reprint, Pittsburg: Duquesne University Press.

Loughran, J. (2010). What expert teachers do: Enhancing professional knowledge for classroom practice. Crows Nest, NSW: Allen \& Unwin.

Lyotard, J-F. (1979). La Condition Postmoderne: Rapport le Savoir. Paris: Minuit (The postmodern condition: A report on knowledge. Manchester: University Press, 1984, Trans.).

Madden, R. (2017). The practice room: A space for teachers to engage in dialogue about learning in religious education. In K. Smith \& J. Loughran (Eds.), Quality learning: Teachers changing their practice (pp. 127-140). Rotterdam: Sense Publishers.

Pollefeyt, D. (2009). Belgium: The Hermeneutic-Communicative option a feasible option? In H. Ziebertz \& U. Riegel (Eds.), How teachers in Europe teach religion: An international empirical study in 16 countries (pp. 31-43). Berlin: LIT-Verlag.

Pollefeyt, D. (2008). The difference of alterity: A religious pedagogy for an interreligious and interideological world. In J. DeTavernier, J. Selling, J. Verstraeten, \& P. Schotsmans (Eds.), Responsibility, God and society: Festschrift Roger Burggraeve (pp. 305-330). Leuven: Peeters.

Pollefeyt, D., \& Bouwens, J. (2014). Identity in dialogue: Assessing and enhancing Catholic school identity. Berlin: Lit Verlag.

Rodgers, C., \& Scott, K. (2008). The development of the personal self and professional identity in learning to teach. In M. Cochran-Smith, S. Feiman-Nemser, \& J. McIntyre (Eds.), Handbook of research on teacher education: Enduring questions in changing contexts (3rd ed., pp. 732-756). New York: Routledge.

Skott, J. (2015). The promises, problems and prospects of research on teachers' beliefs. In H. Fives \& M. Gregoire-Gill (Eds.), International handbook of research on teachers' beliefs (pp. 17-20). New York: Routledge.

Smagorinsky, P., Cook, L., Moore, C., Jackson, A., \& Fry, P. (2004). Tensions in learning to teach: Accomodations and the development of a teaching identity. Journal of Teacher Education, 1(55), 8-24.

Sunley, R. (2009). Relating to the spiritual in the classroom. In M. de Souza, L. Francis, J. O'HigginsNorman, \& D. Scott (Eds.), International handbook of education for spirituality, care and wellbeing (pp. 793-808). Dordrecht, London, New York: Springer.

Tacey, D. (2000). Reenchantment: The new Australian spirituality. Sydney: Harper Collins.

Timperley, H., Wilson, A., Barrar, H., \& Fung, I. (2007). Teacher professional learning and development: Best evidence synthesis iteration. New Zealand Ministry of Education. Retrieved November 15, 2019, from https://www.oecd.org/education/school/48727127.pdf.

Tracy, D. (1979). Blessed rage for order: The new pluralism in theology. New York: The Seabury Press.

Vatican Council II. (1965). Gaudium Et Spes. Pastoral Constitution on the Church in the Modern World. Retrieved April 28, 2020, from https://www.vatican.va/archive/hist_councils/ii_vatican_council/ documents/vat-ii_cons_19651207_gaudium-et-spes_en.html.

Vatican Council II. (1965). Dei Verbum. Dogmatic Constitution on Divine Revelation. Retrieved April 28, 2020, from https://www.vatican.va/archive/hist_councils/ii_vatican_council/documents/vat-ii_const _19651118_dei-verbum_en.html.

Zembylas, M. (2003). Emotions and teacher identity: A poststructural perspective. Teachers and Teaching: Theory and Practice, 3(9), 214-238.

Publisher's Note Springer Nature remains neutral with regard to jurisdictional claims in published maps and institutional affiliations. 